\title{
Bacterial contamination of packaged smokeless tobacco sold in India
}

\author{
Rashmi Mehra', Vikrant Mohanty', Aswini Y. Balappanavar', Shivam Kapoor ${ }^{1}$
}

\begin{abstract}
INTRODUCTION About 21.4\% of India's population uses smokeless tobacco products (SLT), yet limited data are available on their microbial contamination. To understand the potential microbiological risks associated with SLT use, the present study aims to investigate bacterial contamination of tobacco and the types of microbes that could be cultured from SLT products.

METHODS Twenty-two brands of SLT products, including paan masala, khaini, gutka and tobacco-containing dentifrices were examined and cultured by using appropriate selective and differential media including MacConkey agar and CLED agar. This was followed by a sequence of further identification by biochemical tests.

RESULTS All 22 types of SLT products showed growth of aerobic bacteria. The most common bacteria isolated were Pseudomonas aeruginosa followed by Streptococcus faecalis. Other bacteria that were isolated from products, in traces, included Klebsiella spp., E. coli, and Bacillus subtilus.

CONCLUSIONS This study raises and addresses the issue of bacterial contamination of packaged SLT products. SLT users might be subjected to a significant health hazard, especially those who are immunocompromised.
\end{abstract}

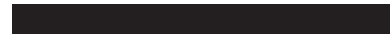

\section{AFFILIATION}

1 Department of Public Health Dentistry, Maulana Azad Institute of Dental Sciences, New Delhi, India

\section{CORRESPONDENCE TO}

Rashmi Mehra. Department of Public Health Dentistry, Maulana Azad Institute of Dental Sciences, New Delhi, India.

E-mail: rm17111991@gmail.com

\section{KEYWORDS}

contamination, bacteria, toxicology, smokeless tobacco, tobacco constituents

\section{Received: 27 March 2019} Revised: 28 September 2019

Accepted: 4 December 2019

\section{INTRODUCTION}

According to the Global Adult Tobacco Survey (GATS) 2016-2017, 21.4\% of India's population uses smokeless tobacco products (SLT) ${ }^{1}$. Smokeless tobacco use consists of chewing paan (mixture of lime, pieces of areca nut, tobacco and spices wrapped in betel leaf), chewing gutka or paan masala (scented tobacco mixed with lime and areca nut, in powder form), and mishri (a kind of toothpaste used for rubbing on gums). India has one of the largest number and relative share of tobacco users in the world ${ }^{2}$. It has been estimated that $90 \%$ of oral cancer cases in India are attributable to tobacco use of any kind ${ }^{3}$. A review by Boffeta et al. ${ }^{4}$ estimated that more than half of all oral cancers in India are caused by SLT use.

Unlike smoked forms of tobacco, SLT relies on absorption of nicotine through the oral mucosa $\mathrm{a}^{5}$. In terms of toxicity, SLT products are commonly thought to be less toxic than smoked products even though they are associated with many adverse health effects including nicotine addiction, oral lesions, oral and pancreatic cancer, and cardiovascular disease ${ }^{6}$. Many of these adverse health outcomes are attributed to chemical carcinogens present in smokeless tobacco products including tobacco-specific nitrosamines (TSNAs) and polycyclic aromatic hydrocarbons ${ }^{6}$. TSNAs are thought to be among the most important tobacco-associated carcinogens due to their toxicity and high abundance in SLT products ${ }^{7}$. Different TSNAs are formed from the reaction of alkaloids with nitrite $^{8}$, and levels of available nitrite are influenced by nitrite-reducing bacteria that are known to be part of a variety of bacteria, or microbiota, associated with tobacco products9.

SLT manufacturing in India falls into two categories: registered/organised and unregistered/ 
unorganised. The estimated share of SLT production by the unorganised sector was $11 \%$ in $2011^{10}$. Further, different SLT products manufactured in India undergo various processes of curing and mixing. Plain chewing tobacco is sold in sachets along with a pack of slaked lime which the user can mix. Gul (tobacco containing dentifrice) is a dry powder-like tobacco preparation made using fine tobacco leaf dust, molasses, lime, and red soil. It is then packaged into plastic sachets or tin boxes. Gutka is a wet non-perishable paan substitute, commercially manufactured containing areca nut, slaked lime, catechu, sun dried tobacco leaves, flavourings, and sweeteners. Loose locally sold tobacco leaves are manufactured using an air-curing process. Most products are sold in plastic packaging to ensure longer shelf life. Each step tends to be a potential inception ground for contamination as there are no stipulated guidelines for quality control and avoidance of microbiological contamination of tobacco products.

In 2010, to curtail environmental effects of tobacco product packages, directions were issued to ban the sale of tobacco products like gutka, tobacco and paan masala in plastic pouches. The Ministry of Environment and Forests finalised an enforced this regulation by March 2011. They are packed in various sizes and materials including plastics and paper packaging, stored in differing climatic and geographic conditions at various tobacco kiosks across the country ${ }^{2}$.

Microbiological contamination of SLT along with the impact of varying climatic and geographic conditions might pose an additional risk by altering the nature of the intended constituents of the packaged SLT product. Further, microbiological contamination might contribute to the conversion of nitrites and alkaloids into TSNAs, which are major carcinogenic agents. Hence, the present study was conducted with the aim to investigate bacterial contamination of commercially available SLT products and the types of bacteria that could be cultured from them.

\section{METHODS}

\section{Product sampling}

The study was conducted in two phases. The first phase was the collection of commercially available SLT products followed by a second phase that included microbiological analysis of the collected products. Ethical clearance was obtained from the Institutional Ethical Review Board before product analysis.

In our study, we have included only the SLT products manufactured by the organised sector. The city of Delhi is geographically divided into 5 zones, namely North, South, East, West and Central. The Central zone of Delhi was chosen based on convenience for collection of samples. A single investigator collected commercially available SLT products from tobacco shops located in the Central zone till no new products were found. The study was conducted in October 2018.

The current study included a total of 22 products including 7 brands of paan masala, 7 gutka, 6 khaini, and 2 tobacco containing dentifrices. Following collection, the products were identified, noting the batch number and date of manufacture if mentioned.

\section{Sample analysis}

For the second part of the study, all samples were transported and stored at room temperature prior to examination. The purchased products were then placed in a UV chamber for 30 minutes to ensure decontamination of the outer surface of the packets. In addition, all laboratory tools that were used during experiments were sterilized by autoclaving and flame sterilized immediately prior to use.

One gram of each product was dissolved in $10 \mathrm{~mL}$ of normal saline solution. After appropriate mixing, samples were centrifuged and cultures prepared by spreading $0.1 \mathrm{~mL}$ of each sample on different media and incubated for $48-72$ hours at $37^{\circ} \mathrm{C}$. The number of estimated colony-forming units (CFU) for each sample was counted. Discrete colonies of aerobic bacteria were sub-cultured for purification by streaking in fresh solid media ${ }^{11}$.

The following media were used as per the American Public Health Association (APHA 1985) ${ }^{12}$ and World Health Organization (WHO 1997) ${ }^{13}$ guidelines.

Further identification of isolated bacteria was made by gram staining and biochemical tests (oxidase test, urease test, coagulase test, Indole production test, and citrate utilisation test). These tests were performed according to Finegold and Baron ${ }^{14}$. A modified summary of the testing performed is provided in Figure 1. 
Figure 1. Modified summary of biochemical tests performed

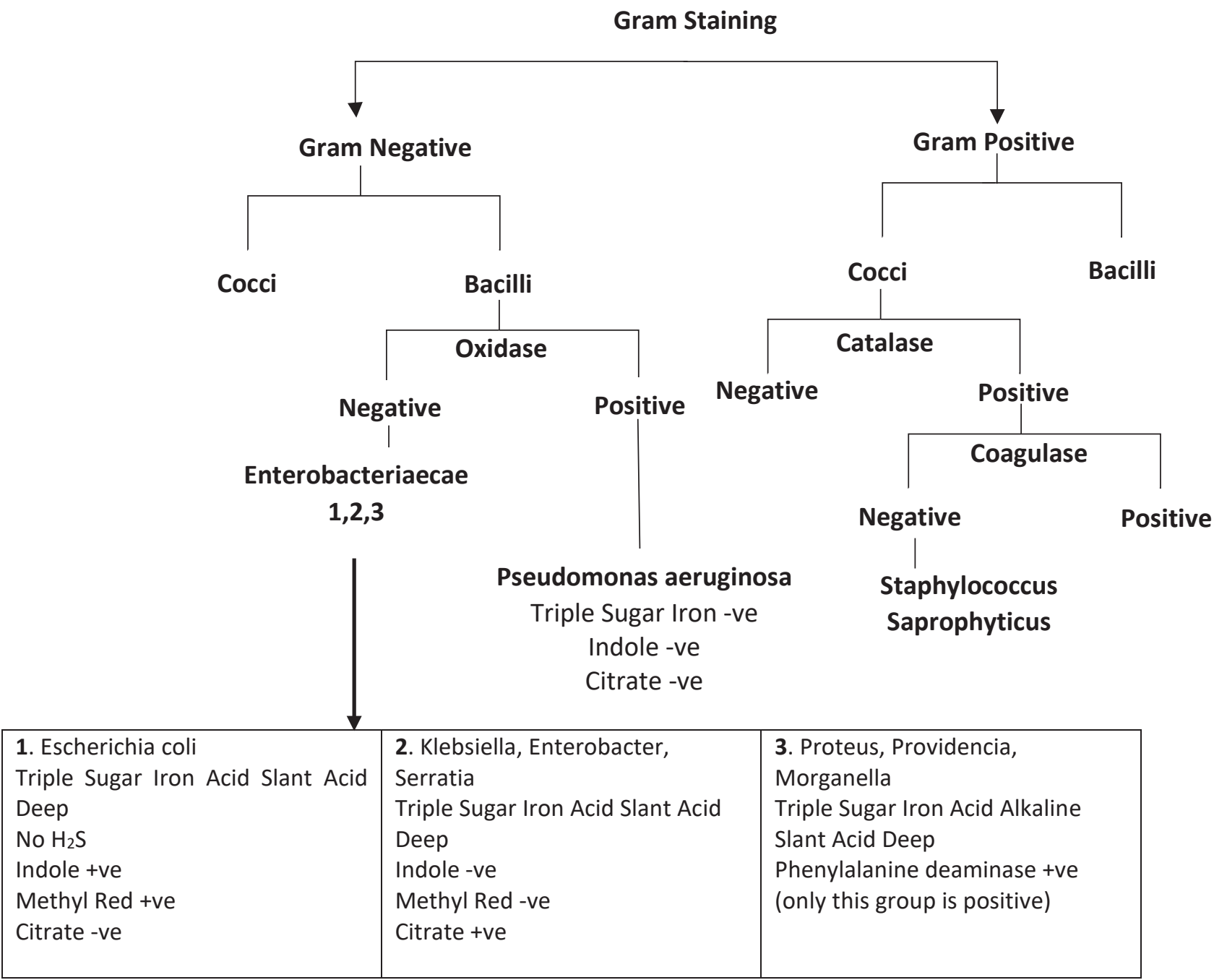

\section{Data analysis}

Data obtained were entered on a digital spreadsheet using Microsoft Excel 2016. Descriptive inferences were derived and plotted in the form of bar diagrams and charts.

\section{RESULTS}

A total of 22 brands of SLT products were analysed for bacterial contamination using culture and incubation for 48-72 hours. All 22 brands of SLT were found to have bacterial contamination. The most commonly isolated bacteria were Pseudomonas aeruginosa, Streptococcus faecalis, E. coli, and Klebsiella pneumoniae (Figure 2).

Of the 4 types of SLT products analysed, all brands of gutka were found to have the highest colony-
Figure 2. Bacterial contamination of SLT product

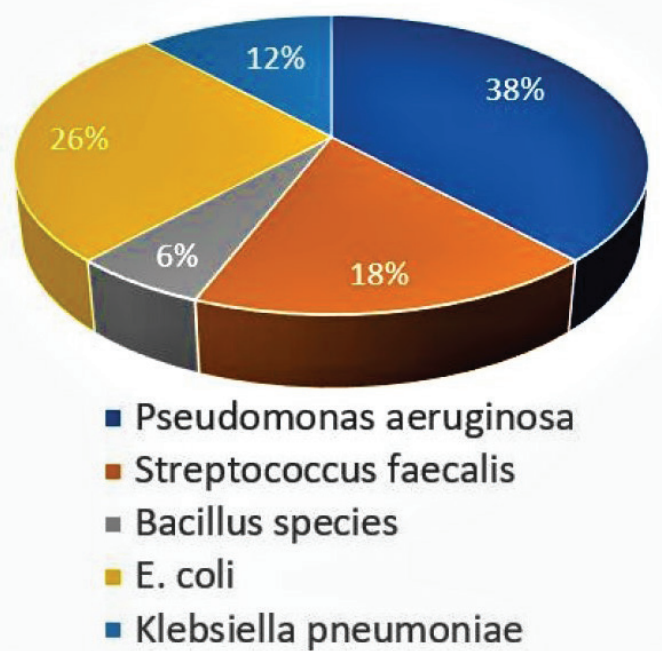


Figure 3. Bacteria isolated from SLT products

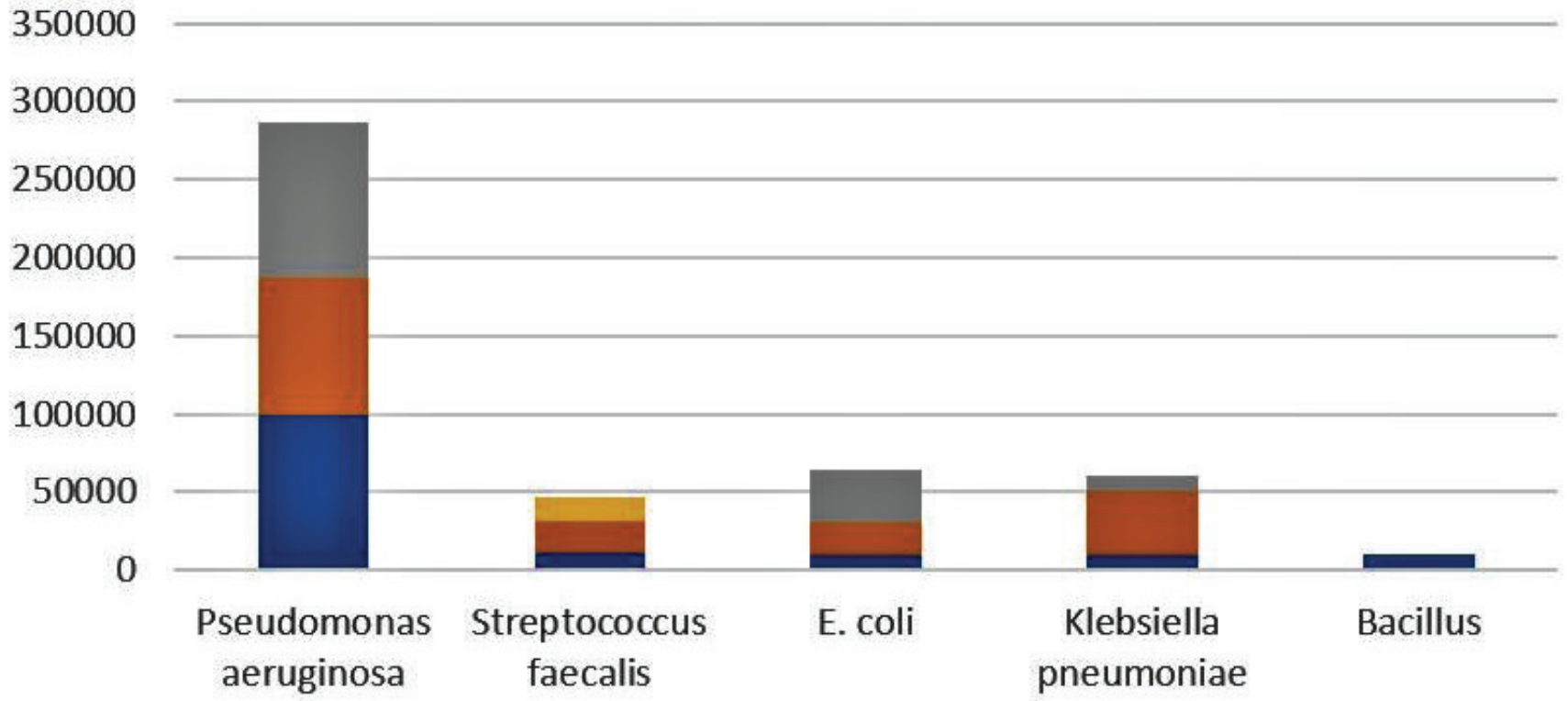

Pan Masala Gutka Khaini $=$ Tobacco containing dentifrices

forming units followed by plain tobacco, paan masala and then by tobacco-containing tooth powder. The distribution of the isolated bacteria varied across brands, shown in Figure 3. The distribution of the five most commonly isolated bacteria, among four categories of SLT products, differed across products and bacteria. Pseudomonas aeruginosa were the most commonly isolated bacteria with a mean CFU of $0.9 \times 10^{5}$. This was followed by $E$. coli, and the least commonly isolated bacteria being Bacillus subtilis.

\section{DISCUSSION}

Our study identified bacterial contamination of SLT products in India. The microbial content of SLT products placed in the oral cavity for long periods could be a health threat, especially to tobacco users who are immunocompromised. Long-term use of oral SLT has been associated with the development of oropharyngeal and upper respiratory-tract cancers and is a risk factor for cardiovascular disease and adverse reproductive outcomes ${ }^{15,16}$. In addition to the carcinogenic effects of SLT, the TSNA content of these products is associated with reported oral adverse effects including gingival recession, caries, staining, and abrasion ${ }^{17}$.

A total of 22 SLT products available in the market were analysed for contamination using bacterial culture. The number of brands to be included was based on previous studies conducted on SLT products in countries other than India ${ }^{18-20}$. All products were found to be contaminated with bacteria. This observation is particularly remarkable considering a previous report suggesting SLT products are microbiologically safe and stable ${ }^{21}$ - the results of the present study question the microbiological safety of SLT products available in the Indian market.

Tobacco, like any other agricultural product, undergoes processes of cultivation, harvesting, processing, and packaging. During the cultivation of tobacco, bacteria are present at approximately 105 organisms per gram of leaf material. At harvest, tobacco is not generally washed, thus leaves with deposited microorganisms and agricultural chemicals will be processed, and the contaminants will be present in the final product. During the subsequent curing step, the tobacco leaves are dried and bacteria, which proliferate to levels 10 to 20 times higher than on the growing leaf ${ }^{22}$, begin converting the nitrate present in the plant tissue to nitrite, a process called nitrate reduction. Once nitrite is produced, a chemical process of nitrosation occurs in which 
nitrite reacts with tobacco alkaloids to generate TSNAs $^{23}$. Amine compounds, other than tobacco alkaloids, can also react with nitrite to form nonvolatile $\mathrm{N}$-nitrosamines, volatile nitrosamines, and $\mathrm{N}$-nitrosamino acids $^{24,25}$.

The most commonly isolated bacteria from SLT products were Pseudomonas aeruginosa. The results of this study are similar to those of studies conducted in other parts of the world ${ }^{10,26}$. The bacteria isolated included Pseudomonas aeruginosa, Streptococcus faecalis, E. coli, Klebsiella pneumoniae, and Bacillus subtilus. This result is similar to the reports of Rubinstein and Pederson ${ }^{27}$, Ayo-Yusuf et al. ${ }^{28}$, Alsaimary et al. ${ }^{19}$, Okechi et al. ${ }^{29}$, Onuorah and Orji ${ }^{30}$, and Tyx et al. ${ }^{31}$, who reported the detection of some of these isolates, in contrast to the report of Ahamed $^{32}$ who mainly found Bacillus species. The health risks associated with most of these bacterial isolates have been reported by Hardy et al. ${ }^{33}$. Factors such as lack of proper heat treatment during the fire-curing process of raw tobacco leaves can also produce contaminated products, especially if the leaves were infected as reported by Szedljak ${ }^{34}$. The hygroscopic nature of dried tobacco leaves and snuff was previously suggested to create a suitable environment for the growth of contaminating microorganisms ${ }^{35}$. Some of these might be important in the fermentation of raw tobacco leaves to produce the desired flavour. In contrast, the varieties of bacteria in the current study are not normal flora of tobacco but mainly of human origin and could be thought to have resulted from human contamination. Some of these microorganisms have been reported as potentially pathogenic to humans ${ }^{36}$.

The microbial populations that contaminate SLT products across the pre-processing, processing and post-processing lines may impact negatively on the health of SLT users due to their pathogenic potentials. The bacteriological examination of locally sold SLT products in Delhi revealed a microbial burden when compared with stipulated guidelines for microbiological food safety given for various food products.

WHO Framework Convention on Tobacco Control (Articles 9 and 10) provides guidelines for the regulation of contents of tobacco products. However, the guidelines give no direction for microbiological contamination of finished tobacco products. In
India, the Food Safety and Standards Authority of India (FSSAI) is responsible for protecting and promoting public health through the regulation and supervision of food safety. However, under various rulings given by the Judiciary various SLT products including paan masala do not come under food and are solely governed by the Cigarettes and Other Tobacco Products Act (COTPA) and associated laws. Unfortunately, the COTPA does not provide any microbiological standards or stipulated levels for the already harmful tobacco products. The Ministry of Health and Family Welfare, Government of India, has made major strides and has successfully launched the National Tobacco Testing Laboratories across the nation at Noida, Mumbai, and Guwahati. This would aid in the monitoring of tobacco product constituents and regulating the same in the future.

\section{Limitations}

The present study has some inherent limitations. In our study, we could include only a few locally available packaged SLT products, limiting the information that could be collected. The methodology could be further strengthened by collecting samples of varying batches of the same product, collected through different seasons of the year. This would have shed light on the seasonal changes in the microbial contamination of the SLT products. Also, since all the samples were collected from a convenient location, the effect of varying geographical location of production could not be taken into account. Only aerobic bacteria were assessed as part of this study, leaving a plethora of other contaminating organisms still unidentified. Future studies with greater number of brands and batches should be conducted with advanced PCR techniques for the identification of the contaminating microbes. This study also could not assess the products manufactured from unregistered tobacco product producers, which in itself is an ever-booming elusive industry.

\section{CONCLUSIONS}

This study was undertaken to gain understanding of the bacterial populations that may be present in SLT products. Bacterial populations in these products need to be monitored for the protection of public health, and for the FSSAI and COTPA, as this should be incorporated under new regulations of tobacco 
products manufacture. One of the potential risks for SLT users is that the products could act as carriers of pathogenic or opportunistic microorganisms that might culminate in the development of infectious disease. Since most SLT products are typically held for extended periods in close contact with the oral mucosa, it becomes a matter of concern. The development of microbial metabolic by-products that might be harmful to consumers, such as microbial toxins and carcinogens, could be an added potential risk associated with microbial contamination. This study has raised and assessed the issue of bacterial contamination of packaged SLT products, but as this study was the first of its kind conducted in India, much remains shrouded due to lack of research initiatives on this issue. Owing to the lack of regulations on the production of SLT products, users might be subjected to a greater health hazard, especially those who are immunocompromised.

\section{REFERENCES}

1. International Institute for Population Sciences, Ministry of Health and Family Welfare, Government of India. Global Adult Tobacco Survey, India, 2016-2017. New Delhi: Ministry of Health and Family Welfare, Mumbai: International Institute for Population Sciences; 2017. https://www.who.int/tobacco/surveillance/survey/ gats/GATS_India_2016-17_FactSheet.pdf. Accessed September 28, 2019.

2. Gupta PC, Arora M, Sinha D, et al. Smokeless tobacco and public health in India. New Delhi, India: Ministry of Health and Family Wellfare; 2016. https://www.mohfw. gov.in/sites/default/files/Final\%20Version $\% 20$ of $\% 20$ SLT\%20Monograph.pdf. Accessed September 28, 2019.

3. Parkin D, Läärä E, Muir C. Estimates of the worldwide frequency of sixteen major cancers in 1980. Int J Cancer. 1988;41(2):184-197. doi:10.1002/ijc.2910410205

4. Boffetta P, Hecht S, Gray N, Gupta P, Straif K. Smokeless tobacco and cancer. Lancet Oncol. 2008;9(7):667-675. doi:10.1016/s1470-2045(08)70173-6

5. Tomar S, Henningfield J. Review of the evidence that $\mathrm{pH}$ is a determinant of nicotine dosage from oral use of smokeless tobacco. Tob Control. 1997;6(3):219-225. doi:10.1136/tc.6.3.219

6. Stepanov I, Jensen J, Hatsukami D, et al. New and traditional smokeless tobacco: Comparison of toxicant and carcinogen levels. Nicotine Tob Res. 2008;10(12):17731782. doi:10.1080/14622200802443544

7. Stepanov I, Jensen J, Biener L, Bliss R, Hecht S, Hatsukami D. Increased Pouch Sizes and Resulting Changes in the Amounts of Nicotine and Tobacco-Specific N-Nitrosamines in Single Pouches of Camel Snus and
Marlboro Snus. Nicotine Tob Res. 2012;14(10):12411245. doi:10.1093/ntr/ntr292

8. Wei X, Deng X, Cai D, et al. Decreased Tobacco-Specific Nitrosamines by Microbial Treatment with Bacillus amyloliquefaciens DA9 during the Air-Curing Process of Burley Tobacco. J Agric Food Chem. 2014;62(52):1270112706. doi:10.1021/jf504084z

9. Fischer M, Schmidt C, Falke D, Sawers R. Terminal reduction reactions of nitrate and sulfate assimilation in Streptomyces coelicolor A3(2): identification of genes encoding nitrite and sulfite reductases. Res Microbiol. 2012;163(5):340-348. doi:10.1016/j.resmic.2012.05.004

10. Orji JO, Nwobashi PA, Nnachi AU, et al. Bacterial burden and potential public health risks of locally made snuffs sold in Ebonyi state, Nigeria. Int J Curr Microbiol App Sci. 2014;3(9):366-373.

11. Cheesbrough M. Biochemical Test to Identify Bacteria: District Laboratory Practice in Tropical Countries. 2nd ed. London, United Kingdom: Cambridge University Press; 2006.

12. American Public Health Association.Standard methods for examination of water and waste water. 5th ed. Washington, DC: American Public Health Association; 2010.

13. World Health Organization. Guide lines for drinking - water quality vol 3: Surveillance and control of community supplies. Geneva, Switzerland: World Health Organization; 1997.

14. Finegold SM, Baron EJ. (2007). Bailey's and Scott's diagnostic microbiology. 7 th ed. St. Louis, MO: the C.V. Mosby Co; 2007.

15. Winn DM, Blot WJ, Shy C, et al. Snuff dipping and oral cancer amongwomen in the Southern United States. N Engl J Med. 1981;304(13):745-749. doi:nejm198103263041301

16. England LJ, Levin RJ, Mills JL, et al. Adverse pregnancy outcomes in snuff users. Am J Obstet Gynecol. 2003;189(4):939-943. doi:10.1067/s0002-9378(03)00661-6

17. Winn DM. Tobacco use and oral disease. J Dent Educ. 2001;65(4):306-312. PMID:11336115.

18. Smyth E, Kulkarni P, Claye E, et al. Smokeless tobacco products harbor diverse bacterial microbiota that differ across products and brands. Appl Microbiol Biotechnol. 2017;101(13):5391-5403. doi:10.1007/s00253-017-8282-9

19. Alsaimary IE, Jassim HA, Mezal TJ. Bacterial contamination of various Tobacco Types: Society of Education, India. Adv Biores. 2011;2(1):158-174.

20. Han J, Sanad Y, Deck J, et al. Bacterial Populations Associated with Smokeless Tobacco Products. Appl Environ Microbiol. 2016;82(20):6273-6283. doi:10.1128/aem.01612-16

21. Peiser A, Nocella D, Gray R. Microbiological Safety and Stability of Chewing Tobacco. J Food Prot. 1982;45(5):462-465. doi:10.4315/0362-028x-45.5.462

22. Wiernik A, Christakopoulos A, Johansson L, et al. Effect of 
air-curing on the chemical composition of tobacco. Recent Adv Tob Sci. 1995;21:39-80.

23. Djordjevic M, Gay S, Bush L. Tobacco-specific nitrosamine accumulation and distribution in flue-cured tobacco alkaloid isolines. J Agric Food Chem. 1989;37(3):752756. doi:10.1021/jf00087a040

24. World Health Organization. Betel-quid and Areca-nut Chewing and Some Areca-nut-derived Nitrosamines. In: IARC Monographs on the Evaluation of Carcinogenic Risks to Humans Volume 85. Geneva, Switzerland: World Health Organization, International Agency for Research on Cancer; 2004. http://publications.iarc.fr/103. Accessed September 28, 2019.

25. Hoffmann D, Djordjevic M, Fan J, et al. Five Leading U.S. Commercial Brands of Moist Snuff in 1994: Assessment of Carcinogenic N-Nitrosamines. J Natl Cancer Inst. 1995;87(24):1862-1869. doi:10.1093/jnci/87.24.1862

26. Cockrell WT, Roberts JS, Kane BE, et al. Microbiology of oral smokeless tobacco products. Tobacco Science. 1989;33:55-57.

27. Rubinstein I, Pedersen G. Bacillus Species Are Present in Chewing Tobacco Sold in the United States and Evoke Plasma Exudation from the Oral Mucosa. Clin Vaccine Immunol. 2002;9(5):1057-1060. doi:10.1128/cdli.9.5.1057-1060.2002

28. Ayo-Yusuf O, van Wyk C, van Wyk C. Smokeless tobacco products on the South African market do not inhibit oral bacterial flora: a pilot study. Southern African Journal of Epidemiology and Infection. 2005;20(4):136-139. doi:10.1080/10158782.2005.11441251

29. Okechi RN, Oparaugo JU, Azuwike CO, et al. A Survey on the Microbial Contaminants of Snuff Sold in Local Markets in Imo State, Nigeria. Int J Curr Microbiol App Sci. 2014;3(9):366-373. https://www.ijcmas.com/vol-39/R.N.Okechi,\%20et\%20al.pdf/. Accessed September 28, 2019.

30. Samuel O, Michael O. Microbial Contamination Of Locally-Prepared Snuff Sold At Eke-Awka Market, Anmbra State, Nigeria. American Journal of Life Science Researches. 2016;4(3):74-77. doi:10.21859/ajlsr-040301

31. Tyx RE, Stanfill SB, Keong LM et al. Characterization of Bacterial Communities in Selected Smokeless Tobacco Products Using 16S rDNA Analysis. PLoS ONE. 2016;11(1):e0146939. doi:10.1371/journal.pone.0146939

32. Ahamed AAMS. Bacteria Isolated From Snuff (Nicotiana rustica) Before and after Fermentation. Khartoum, Sudan: University of Khartoum; 2005. http://khartoumspace.uofk. edu/bitstream/handle/123456789/8439/Bacteria $\% 20$ Isolated $\% 20$ From $\% 20$ Sunff $\% 20 \% 28 \mathrm{Nicotiana} \% 20$ rustica $\% 29 \% 20$ Before.pdf?sequence $=1 \&$ isAllowed $=y$. Accesses September 28, 2019.

33. Hardy K, Oppenheim B, Gossain S. A Study of the Relationship Between Environmental Contamination with Methicillin-Resistant Staphylococcus aureus (MRSA) and Patients' Acquisition of MRSA. Infect Control Hosp
Epidemiol. 2006;27(02):127-132. doi:10.1086/500622

34. Szedljak I, Román JM, Szántainé KK et al. Microbiological Feature and Comparison of Different Types of Tobaccos During Fermentation. In: 6th International Conference on Food Science Proceedings; 2004.

35. Wightman WG. The Products of Tobacco. London, United Kingdom: McGraw Hill; 1956.

36. Greenwood D, Slack RCB, Peutherer JF. Medical Microbiology. A Guide to Microbial Infection Pathogenesis Immunity, laboratory Diagnosis and Control. 14th ed. London, United Kingdom: Longman Group; 1992.

\section{CONFLICTS OF INTEREST}

The authors have completed and submitted the ICMJE Form for Disclosure of Potential Conflicts of Interest and none was reported.

\section{FUNDING}

There was no source of funding for this research.

PROVENANCE AND PEER REVIEW

Not commissioned; externally peer reviewed. 